\title{
Wood and Black Liquor-Based N-Doped Activated Carbon for Energy Application
}

\author{
Ance Plavniece ${ }^{1,2, *}$, Aleksandrs Volperts ${ }^{1} \oplus$, Galina Dobele ${ }^{1}$, Aivars Zhurinsh ${ }^{1}$, Kätlin Kaare ${ }^{3}$, \\ Ivar Kruusenberg ${ }^{3}$, Kaspars Kaprans ${ }^{4}$, Ainars Knoks ${ }^{4} \mathbb{D}$ and Janis Kleperis ${ }^{4}$ \\ 1 Latvian State Institute of Wood Chemistry, LV-1006 Riga, Latvia; aleksandrs.volperts@kki.lv (A.V.); \\ galina.dobele@kki.lv (G.D.); aivarsz@edi.lv (A.Z.) \\ 2 Faculty of Material Science and Applied Chemistry, Riga Technical University, LV-1658 Riga, Latvia \\ 3 National Institute of Chemical Physics and Biophysics, 12618 Tallinn, Estonia; katlin.kaare@kbfi.ee (K.K.); \\ Ivar.kruusenberg@kbfi.ee (I.K.) \\ 4 Institute of Solid State Physics, University of Latvia, LV-1063 Riga, Latvia; kasparsk@cfi.lu.lv (K.K.); \\ ainars.knoks@cfi.lu.lv (A.K.); janis.kleperis@cfi.lu.lv (J.K.) \\ * Correspondence: ance.plavniece@kki.lv
}

Citation: Plavniece, A.; Volperts, A.; Dobele, G.; Zhurinsh, A.; Kaare, K.; Kruusenberg, I.; Kaprans, K.; Knoks, A.; Kleperis, J. Wood and Black Liquor-Based N-Doped Activated Carbon for Energy Application. Sustainability 2021, 13, 9237. https:// doi.org/10.3390/su13169237

Academic Editor: Joan J. Manyà

Received: 21 July 2021

Accepted: 13 August 2021

Published: 17 August 2021

Publisher's Note: MDPI stays neutral with regard to jurisdictional claims in published maps and institutional affiliations.

Copyright: (c) 2021 by the authors. Licensee MDPI, Basel, Switzerland. This article is an open access article distributed under the terms and conditions of the Creative Commons Attribution (CC BY) license (https:// creativecommons.org/licenses/by/ $4.0 /)$.

\begin{abstract}
Fuel cells, batteries and supercapacitors are critical to meet the rising global demand for clean, sustainable energy. Biomass-derived activated carbon can be obtained with tailored properties to fulfil the extensive need for low-cost, high-performance, catalyst and electrode materials. To investigate the possibility of nanoporous nitrogen-doped carbon materials as catalysts in fuel cells and electrodes in lithium-ion batteries, biomass precursors were thermochemically activated with $\mathrm{NaOH}$ at $800{ }^{\circ} \mathrm{C}$, nitrogen was introduced using dicyandiamide and doping was performed at $800{ }^{\circ} \mathrm{C}$. The chemical composition, porous structure, texture and electrochemical properties of the obtained materials change depending on the biomass precursor used. It has been found that the most promising precursor of the obtained materials is wood char, both as an oxygen reduction catalyst in fuel cells, which shows better properties than the commercial $20 \% \mathrm{Pt} / \mathrm{C}$ catalyst, and as an anode material in Li-ion batteries. However, catalysts based on black liquor and hybrid material have comparable properties with commercial 20\% Pt/C catalyst and can be considered as a cheaper alternative.
\end{abstract}

Keywords: biomass; activated carbons; porous structure; fuel cells; Li-ion batteries

\section{Introduction}

In terms of energy storage and production, plant biomass takes second place in the world right after fossil- based raw materials and is considered a renewable and affordable alternative. However, the use of renewable resources for electricity production is still insufficient to meet the ever-growing energy demand. Therefore, the importance and necessity of biomass-based energy sources have been emphasized in documents devoted to the world economy and energy forums. Mobile, renewable energy sources are essential for both portable electronics (mobile phones and laptops, etc.) and transportation.

The research and development of fuel cells, supercapacitors, Li- [1], Na- [2] and redox flow battery [3] technologies and their improvement are widely studied around the world. For fuel cells, one of the main problems is high cost, with the platinum catalyst being the main source of expenditure.

One of the most promising approaches to wood processing is pyrolysis, which allows obtaining carbon materials and liquid organic products from biomass [4-6]. In the processing of biomass, catalysts are increasingly used to accelerate chemical transformations, increase the yield of the target product and reduce harmful emissions. Although bioenergy in the modern sense began to develop relatively recently, a traditional approach to obtain biomass-based carbon materials with a developed porous structure, such as sorbents and activated carbons, has been developed and evolved over many years. 
Biomass-derived activated carbons can be obtained with tailored properties to meet the tremendous need for low-cost, high-performance, porous carbons for sustainable technologies [7]. Activated carbon have also shown promising results as electrodes for batteries and supercapacitors [8], and as catalysts for fuel cells [9]. Supercapacitors, batteries and fuel cells are critical for enabling technologies and are at the centre of vast global research and initiatives to meet the rising global demand for clean, sustainable energy [10-15].

Carbon materials have many exceptional properties, such as high specific surface area and good electrical and thermal conductivity [16], which are crucial in energy storage and use cases, e.g., a large surface provides more contact area with electrolyte increasing efficiency, and high conductivity provides lower ohmic polarization loss [17]. It is a known fact that nanoporous carbon materials can be synthesised both from wood and from the products of its chemical processing using chemical activation [18,19]. Alkali metal compounds are the most often used for the synthesis of the previously mentioned materials with a highly developed porosity [20], and potassium hydroxide $(\mathrm{KOH})$ is widely used for this purpose. There is an undeservedly dramatic lack of studies on the use of the $\mathrm{NaOH}$ for the activation of organic raw materials. The possibility to modify activated carbons is another advantage, which expands the field of their application [9,21]. The underlying reasons for this are the chemical composition and structure of carbon materials, which allow obtaining an infinite number of three-dimensional modifications that are capable of reacting with other heteroatoms for the inclusion of functional groups that determine self-organisation, chemical stability and reactivity. Among the various heteroatoms for doping $(\mathrm{N}, \mathrm{B}, \mathrm{P}, \mathrm{S})$, nitrogen is the most favourable for the modification of graphenelike materials, since the sizes of the $\mathrm{N}$ and $\mathrm{C}$ atoms are similar, and a strong covalent bond is formed between them [22]. Nitrogen doping provides active sites, increases electrical conductivity, induces charge polarization and spin density, improves oxygen adsorption and cleavage, and balances $\mathrm{Li} / \mathrm{Na}$ binding and diffusion [7]. Theoretical studies have shown that nitrogen can be viewed as an n-type donor that facilitates the transfer of electrons to carbon [23].

However, due to the many factors influencing the formation of carbon materials, it is rather difficult to understand the necessary parameters of their structure and to determine the optimal conditions for obtaining a product with given characteristics. For carbon materials, the role of ultramicro-, supermicro-, micro-, meso- and macropores in the processes of ion diffusion, which is important for capacity and energy density, has not been sufficiently studied. The formation of a porous structure will also occur in different ways under the same activation conditions of the solid ligno-carbohydrate complex of wood in comparison with the liquid aromatic matrix of lignin with a high content of mineral components (e.g., black liquor). However, only less than $2 \%$ of lignin produced in the pulp and paper industry is used for the production of value-added products [24]. The pulp and paper industry generates extensive amounts of waste materials which could potentially cause serious harm to aquatic life, be implicated in various health problems, and also have an effect on the food chain [25]. The most predominant byproduct available in abundance in pulping mills is black liquor [26], which consists of lignin and polysaccharides and soluble inorganic salt ions [27]. Nowadays, most of the waste materials, including black liquor, are underutilized as an energy source [26,28]. It is important from both points of view, socio-economic and environmental, to find appropriate technology to convert the byproducts of such large industry into highly valuable materials such as activated carbons. The reason why lignin-rich black liquor is a good precursor for producing carbon, lies behind the fact that out of the different wood constituents, lignin gives the highest char yield [29].

The purpose of this study is to gain new knowledge for obtaining nanostructured carbon materials using liquid and solid precursors, as well as their mixture. The effect of precursor choice on the pore size distribution is investigated, and the application of renewable resources, wood and its processing byproduct from obtaining cellulose, black liquor, as catalyst in fuel cells and for Li-ion battery electrodes is studied. 


\section{Materials and Methods}

To synthesise activated carbon, two precursors were used: alder wood char (Ltd "Fille", Latvia) and black liquor (Horizon Pulp \& Paper Ltd, Kehra, Estonia). Black liquor is a byproduct of the kraft pulping process, which is an aqueous solution ( $45 \%$ dry content) of lignin residues, hemicellulose and inorganic chemicals. Before activation, wood char was refined in a planetary mill Pulverisette 5/4 (Fritsch, Germany), and the resulting powder was mixed with $\mathrm{NaOH}$, activator to precursor ratio $\mathrm{K}=3$ ( $\mathrm{NaOH}$ :precursor-3:1) and treated at activation temperature $800{ }^{\circ} \mathrm{C}$ in an argon atmosphere. Activated carbon based on black liquor was obtained using activator ratio $\mathrm{K}=2$ and activation temperature $800{ }^{\circ} \mathrm{C}$ in an argon atmosphere. To obtain hybrid material, wood char and black liquor were first mixed in a mass ratio of 1 to 2 , and then activated using activator ratio $\mathrm{K}=2.5$ and activation temperature $800^{\circ} \mathrm{C}$ in an argon atmosphere.

Nitrogen was introduced into activated samples using dicyandiamide (DCDA) solution in dimethylformamide (DMF) with mass ratio carbon material:DCDA-1:20. The solvent was then removed in a rotary evaporator. Doping was performed at $800{ }^{\circ} \mathrm{C}$ for $1 \mathrm{~h}$ in an argon atmosphere.

Specific surface area $\left(\mathrm{m}^{2} \mathrm{~g}^{-1}\right)$, total, micro- and mesopore volume $\left(\mathrm{cm}^{3} \mathrm{~g}^{-1}\right)$, and average pore width $(\mathrm{nm})$ were determined from nitrogen adsorption isotherms at $77 \mathrm{~K}$ using Nova 4200e (Quantachrome, Boynton Beach, FL, USA) instrument. The structure was characterised using X-ray diffraction analysis XRD (PANalytical X'pert PRO) and Raman spectroscopy (TriVista CRS Confocal Raman Microscope by Spectroscopy \& Imaging $\mathrm{GmbH})$. The morphology of the prepared activated carbon was characterized using an SEM/TEM (Helios 5 UX, Thermo Fisher Scientific, Waltham, MA, USA).

Carbon, nitrogen, hydrogen, sulphur and oxygen content was evaluated using the Vario Macro CHNSO device and using X-ray photoelectron spectroscopy (XPS) (ESCALAB $\mathrm{Xi}$, ThermoFisher).

To evaluate the oxygen reduction reaction on the catalyst surface, rotating disk electrode measurements (RDE) were used. Electrochemical measurements were carried out by employing rotating disc electrode setup from Origalys and Gamry potentiostat Reference $600+$. The typical 5-neck cell was used, saturated calomel electrode (SCE) served as a reference electrode and for auxiliary electrode, graphite rod was used. Glassy carbon (GC) electrodes with a diameter of $5 \mathrm{~mm}$ were used as a substrate material. The catalyst ink concentration was $4 \mathrm{mg} \mathrm{mL}^{-1}$ and the ink also consisted of $4 \mu \mathrm{L}$ of ionomer aQAPS-S14 (2\%) from Hephas Energy per $1 \mathrm{mg}$ of material. The electrodes were prepared by drop coating of $20 \mu \mathrm{L}$ of the ink to the electrode, and the final loading of the catalyst material on the electrode was $0.4 \mathrm{mg} \mathrm{cm}^{-2}$. Measurements were performed in $0.1 \mathrm{M} \mathrm{KOH}$ solution at room temperature $\left(23 \pm 1^{\circ} \mathrm{C}\right)$ in a three-electrode cell by using $\mathrm{Pt}$ foil as a counter and saturated calomel electrode (SCE) as a reference electrode. The solution was saturated with $\mathrm{O}_{2}$ (6.0) to study ORR and for measuring background, the solution was saturated with $\mathrm{N}_{2}$ (5.0). A continuous flow of gases was maintained over the solution during the measurement. The software used for controlling the experiments was Nova 2.1.2 (Metrohm Autolab P.V., Utrecht, The Netherlands) and the potential was applied with a potentiostat/galvanostat Autolab PGSTAT 128N (Metrohm Autolab P.V., The Netherlands). The linear sweep voltammetry (LSV) curves were recorded by varying the rotation rate from $400 \mathrm{rpm}$ to $4400 \mathrm{rpm}(400,800,1200,1600,1900,3600,4400)$.

Electrochemical performance of obtained Li-ion battery anode material was tested using potentiostat Voltalab PGZ-301 and Battery Test Station BioLogic VMP3. Electrochemical measurements were carried out using Swagelok type two electrode cell with a lithium foil (thickness $0.38 \mathrm{~mm}$, purity $99.9 \%$, Sigma Aldrich, St. Louis, MO, USA) as a counter and reference electrode (assembled in an Ar-filled dry glovebox where both moisture and oxygen content were less than $1 \mathrm{ppm}$.) at room temperature. We used $1 \mathrm{M}$ solution of $\mathrm{LiPF}_{6}$ in ethyl carbonate (EC)/dimethyl carbonate (DMC) (1:1) as an electrolyte and Celgard glass fibre as a separator. In order to use Swagelok type electrochemical cell, thin layer of electrode ink (10 mL DMF, $0.1 \mathrm{~g}$ polyvinylidene difluoride (PVDF) and $0.5 \mathrm{~g}$ activated 
carbon) was applied to a flat stainless-steel substrate (discs of $1 \mathrm{~mm}$ thickness and $10 \mathrm{~mm}$ diameter) deposited sample mass was $2 \mathrm{mg}$. After coating, the electrodes were dried in the oven at $160{ }^{\circ} \mathrm{C}$ for $2 \mathrm{~h}$. To examine electrochemical behaviour's cyclic voltammetry, galvanostatic charge-discharge and rate capability measurements were performed.

\section{Results and Discussion}

\subsection{Characterization of the Materials}

This research is devoted to the preparation and study of the properties of nanoporous carbon materials based on three types of precursors with different chemical composition and structure. Thermochemical activation was performed at $800{ }^{\circ} \mathrm{C}$ using $\mathrm{NaOH}$ to wood char (WC) in ratio 1:3, black liquor (BL) 1:2 and mixture (in a ratio of 1:2) of wood char and black liquor 1:2.5. After activation, the samples were demineralized with $10 \%$ hydrochloric acid and rinsed with demineralized water until neutral $\mathrm{pH}$ [22].

Wood, being a lignocellulosic biomass, consists of hemicellulose, cellulose and lignin and small amounts of minerals. On the other hand, due to the splitting of the bonds of the wood components in the kraft-pulping process, black liquor generally consists of lignin and a small part of hemicelluloses dissolved in the aqueous solution of $\mathrm{NaOH}$ and sodium sulphide $\left(\mathrm{Na}_{2} \mathrm{~S}\right)$ [30]. In our case black liquor is an aqueous solution of lignin residues, hemicellulose, and inorganic chemicals used in the process of kraft-pulping $(11.2 \% \mathrm{NaOH}$, $10.9 \% \mathrm{Na}_{2} \mathrm{CO}_{3}$ and $21.9 \% \mathrm{NaHCO}_{3}$ ).

To determine the chemical composition, elemental analysis was performed, and the results are shown in Table 1. After the activation of raw material under the influence of temperature and activator, carbon frameworks with different surface functional groups are formed. Activated wood char (AWC) consists mainly of carbon $(96.18 \%)$ and oxygen $(2.41 \%)$, whereas the activated black liquor (ABL) contains, in addition to the abovementioned carbon (70.07\%), a significant amount of sulphur (15.94\%). Activated carbon based on wood char and black liquor (AWC2BL) is a hybrid material of two raw materials and its chemical composition is in-between AWC and ABL. To improve the surface properties of the carbon materials and introduce new active functional groups, the samples were doped with nitrogen using DCDA. The nitrogen contents after doping are similar for all samples and are within the range from $4.0 \%$ to $4.7 \%$. Judging by these results (Table 1 ) during $\mathrm{N}$-doping, not only oxygen, but part of the sulphur in the ABL sample, are replaced by nitrogen.

Table 1. Yield and elemental composition of activated carbon based on wood char (AWC), activated carbon based on wood char and black liquor (AWC2BL) and activated carbon based on black liquor (ABL) pre- and post-N-doping.

\begin{tabular}{cccccccc}
\hline Material & Yield, $\%$ * & Ash, $\%$ & $\mathbf{N}, \boldsymbol{\%}$ & $\mathbf{C ,} \%$ & $\mathbf{H}, \mathbf{\%}$ & $\mathbf{0}, \mathbf{\%}$ & $\mathbf{S}, \mathbf{\%}$ \\
\hline AWC & 38.5 & 0.01 & 0.72 & 96.18 & 0.69 & 2.41 & 0.13 \\
\hline AWC-N & 34.7 & 0.01 & 4.06 & 93.99 & 0.71 & 1.24 & 0.12 \\
\hline AWC2BL & 11.5 & 3.04 & 0.82 & 87.66 & 2.96 & 5.24 & 3.32 \\
\hline AWC2BL-N & 10.4 & 3.15 & 4.21 & 92.40 & 1.66 & 1.21 & 0.52 \\
\hline ABL & 6.2 & 6.74 & 0.49 & 70.07 & 2.32 & n.a. & 15.94 \\
\hline ABL-N & 5.6 & 6.94 & 4.75 & 86.29 & 2.30 & n.a. & 3.07 \\
\hline * to a.d. raw material mass. & & & & & &
\end{tabular}

One of the most important properties of carbon materials is the pore size distribution, which determines the surface area and mass transfer of chemicals and ionic groups. The thermochemical activation of the lignocellulosic biomass is widely studied for the highly microporous activated carbons [31-35]; however, to improve electrochemical performance, mesopores are also required [36]. The porous structures of the obtained carbon materials pre- and post-N-doping were studied using nitrogen sorption at $77 \mathrm{~K}$ : the isotherms are shown in Figure 1a, and the pore size distributions calculated according to the quenched 
solid density functional theory (QSDFT) are shown in Figure $1 \mathrm{~b}$. The surface areas were calculated according to the Brunauer-Emmet-Teller (BET) theory and are shown in Table 2. As can be seen, all of the activated samples have a specific surface area of more than $2000 \mathrm{~m}^{2} \mathrm{~g}^{-1}$, proving that activation was highly efficient. However, the structure and pore size distribution of the samples under study are related to the raw material's chemical composition and structure. In Figure 1a, the shape of the AWC-N isotherm is characteristic for microporous sorbents, but in the case of ABL-N adsorption-desorption the isotherm forms a hysteresis, which points to the significant input of the mesoporous structure into the porous structure.

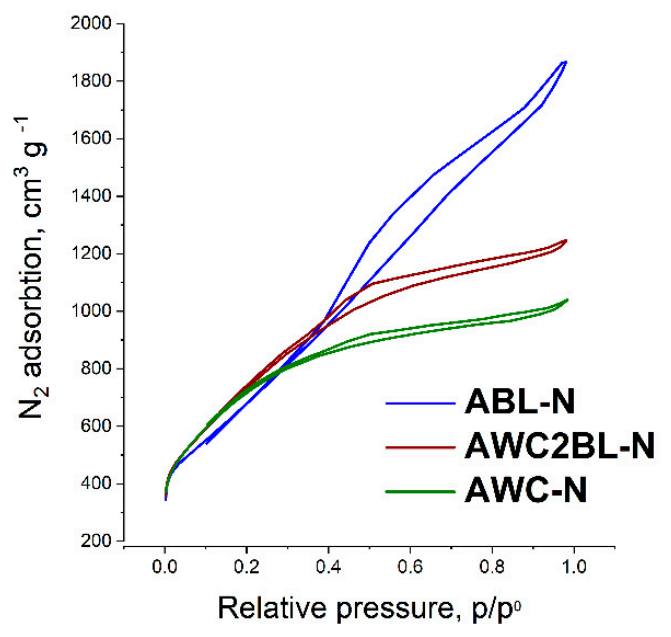

(a)

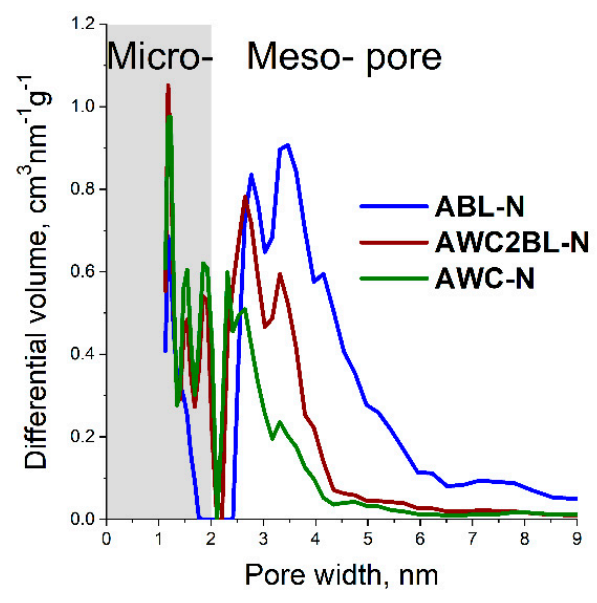

(b)

Figure 1. $\mathrm{N}_{2}$ adsorption-desorption isotherms (a) and pore size distribution (b) of N-doped activated carbon based on wood char (AWC), activated carbon based on wood char and black liquor (AWC2BL) and activated carbon based on black liquor $(\mathrm{ABL})$.

Table 2. Porous structure of activated carbon based on wood char (AWC), activated carbon based on wood char and black liquor (AWC2BL) and activated carbon based on black liquor (ABL) pre- and post-N-doping.

\begin{tabular}{|c|c|c|c|c|c|}
\hline Material & $\begin{array}{c}\text { Specific Surface } \\
\text { Area }(B E T), \mathrm{m}^{2} \mathrm{~g}^{-1}\end{array}$ & $\begin{array}{c}\text { Total Pore } \\
\text { Volume, } \mathrm{cm}^{3} \mathrm{~g}^{-1}\end{array}$ & $\begin{array}{c}\text { Micropore } \\
\text { Volume, } \mathrm{cm}^{3} \mathrm{~g}^{-1}\end{array}$ & $\begin{array}{c}\text { Mesopore } \\
\text { Volume, } \mathrm{cm}^{3} \mathrm{~g}^{-1}\end{array}$ & $\begin{array}{l}\text { Average Pore } \\
\text { Width, (nm) }\end{array}$ \\
\hline AWC & 2733 & 1.52 & 0.86 & 0.66 & 2.23 \\
\hline AWC-N & 2631 & 1.60 & 0.82 & 0.79 & 2.44 \\
\hline AWC2BL & 2754 & 1.91 & 0.87 & 1.04 & 2.77 \\
\hline AWC2BL-N & 2690 & 1.92 & 0.84 & 1.08 & 2.87 \\
\hline $\mathrm{ABL}$ & 2104 & 2.35 & 0.68 & 1.67 & 4.42 \\
\hline ABL-N & 2481 & 2.88 & 0.82 & 2.06 & 4.66 \\
\hline
\end{tabular}

The total micro- and mesopore volume, as well as the average pore sizes are shown in Table 2: the microspore volumes for all samples are similar and with the increase in total pore volume, the mesopore volume increases and reaches a maximum in the case of ABL-N $2.06 \mathrm{~m}^{3} \mathrm{~g}^{-1}$. Consequently, the average pore size is also the highest in this case$4.66 \mathrm{~nm}$. Mesopore size changes in the range 2-4.5 nm for AWC-N and up to 2-10 nm for ABL-N, accompanied by the mesopores' volume increase. As expected, the porous structure of the AWC2BL-N hybrid material has a higher mesopore volume than AWC-N, and lower compared to ABL-N, which allows to adjust the properties of the activated carbon depending on the goal. 
The microstructure of the $\mathrm{N}$-doped activated carbons was studied using SEM and is shown in Figure 2a,c,e. AWC-N and AWC2BL-N particle surface displayed a wavy, wrinkled layered carbon morphology. In contrast, ABL-N particles are rough layered agglomerates. The TEM image of AWC2BL-N (Figure 2d) shows a dense particle, coated with several graphenelike layers and the ABL-N (Figure 2f) particle is dense and layered with a less dense structure at the outer edges, where the AWC-N (Figure 2b) displayed transparent wavy layers with a graphenelike shell and denser multilayer core.

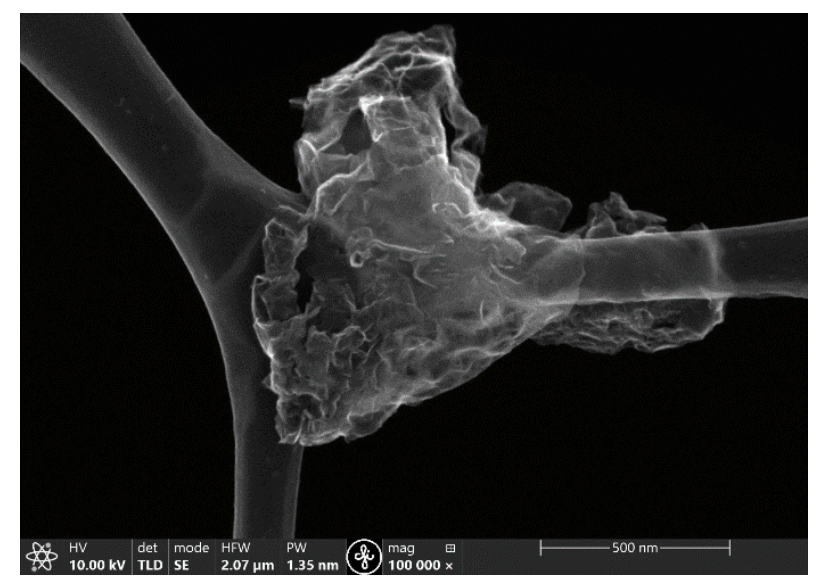

(a)

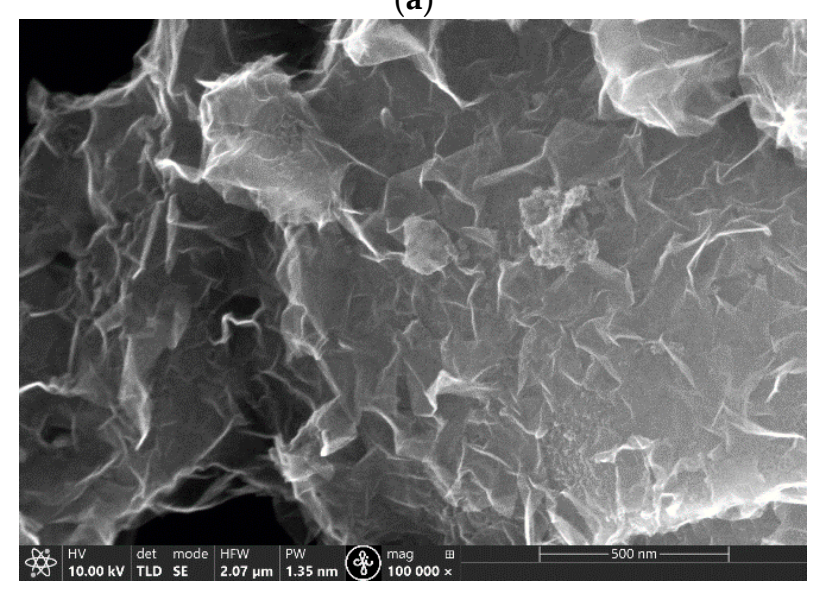

(c)

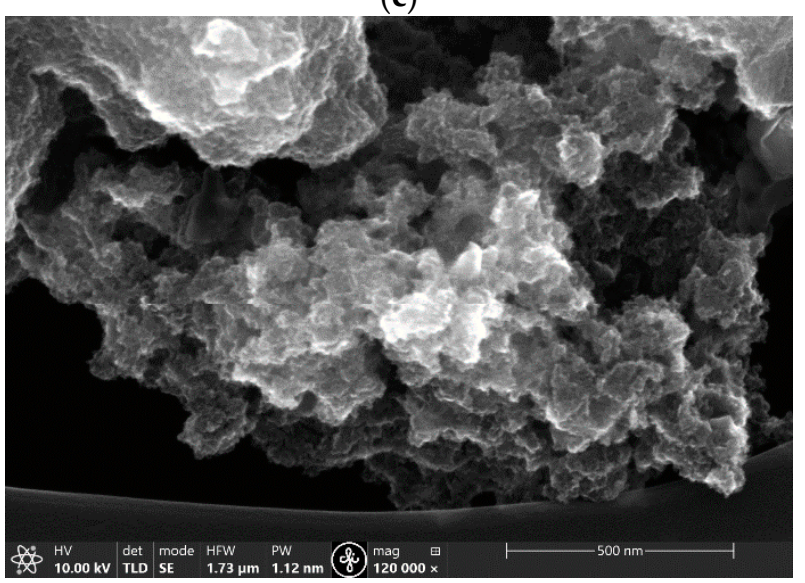

(e)

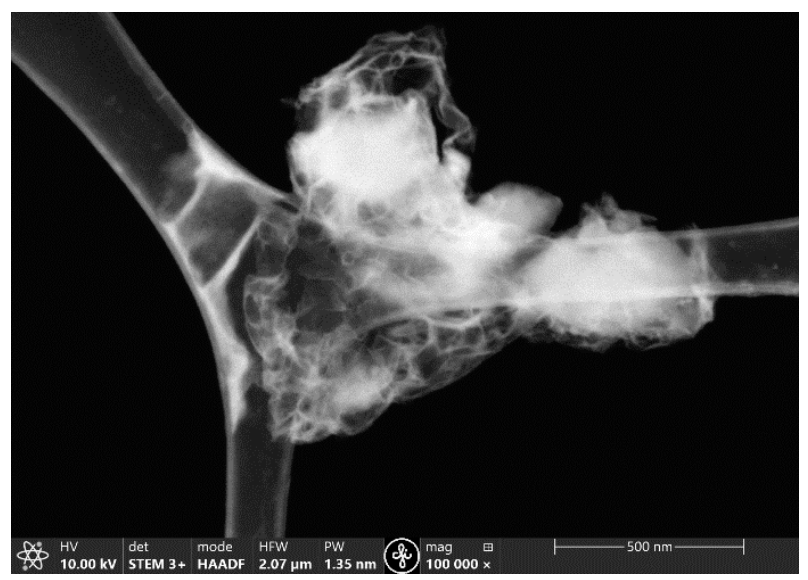

(b)

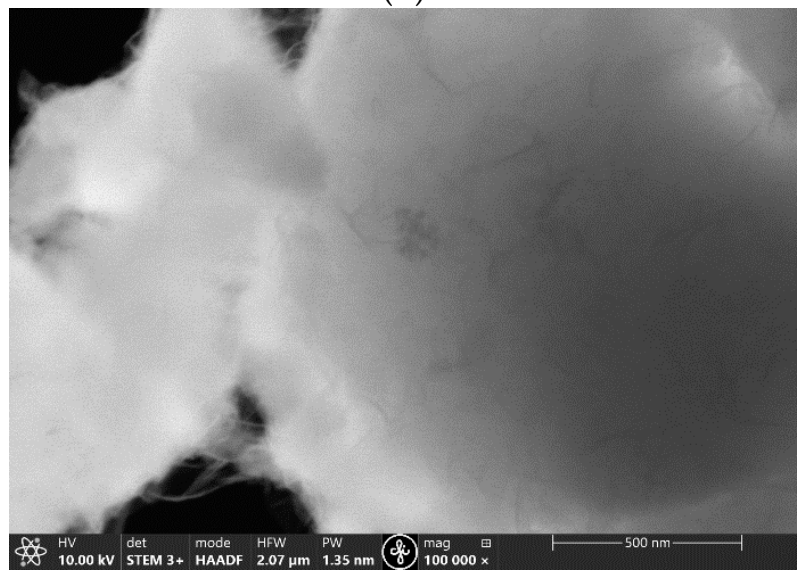

(d)

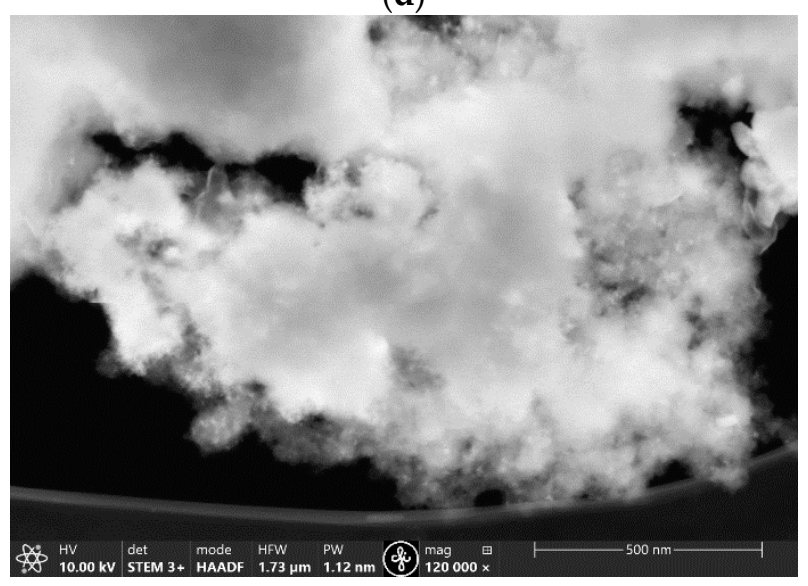

(f)

Figure 2. SEM images of (a) N-doped activated carbon based on wood char (AWC-N), (c) N-doped activated carbon based on wood char and black liquor (AWC2BL-N) and (e) N-doped activated carbon based on black liquor (ABL-N). TEM images of (b) AWC-N, (d) AWC2BL-N and (f) ABL-N. 
The surface elemental composition was studied using XPS. From the overview spectra (Figure 3a), it is possible to distinguish between carbon, oxygen and nitrogen peaks and their relative contents were calculated and the obtained results are comparable with the literature data $[37,38]$. Although sulphur is detected in the ABL-N sample by elemental analysis, it was not found on the surface of the sample using XPS $(164,228 \mathrm{eV})$ [39], indicating that sulphur is deeply embedded into the carbon structure. Oxygen reduction reactions (ORR) activity can be improved by doping with nitrogen and sulphur, which change the local charge density and spin density of carbon material [40].

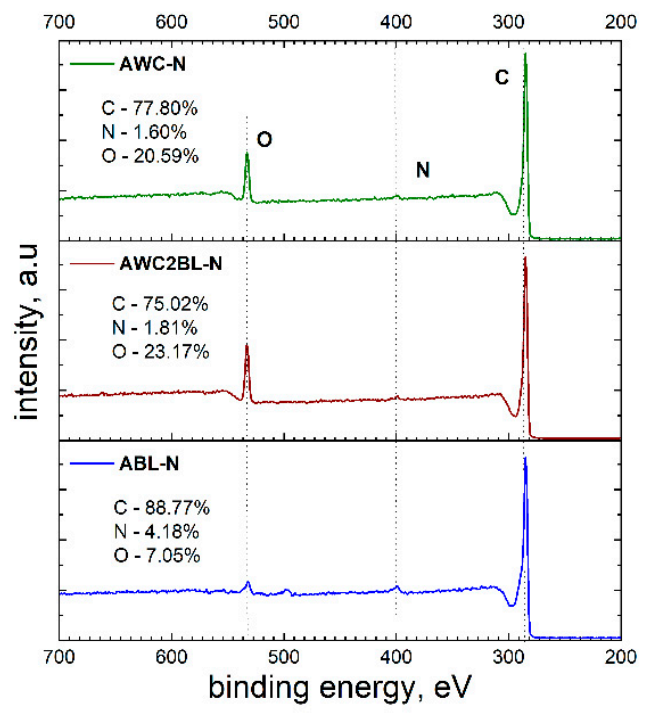

(a)

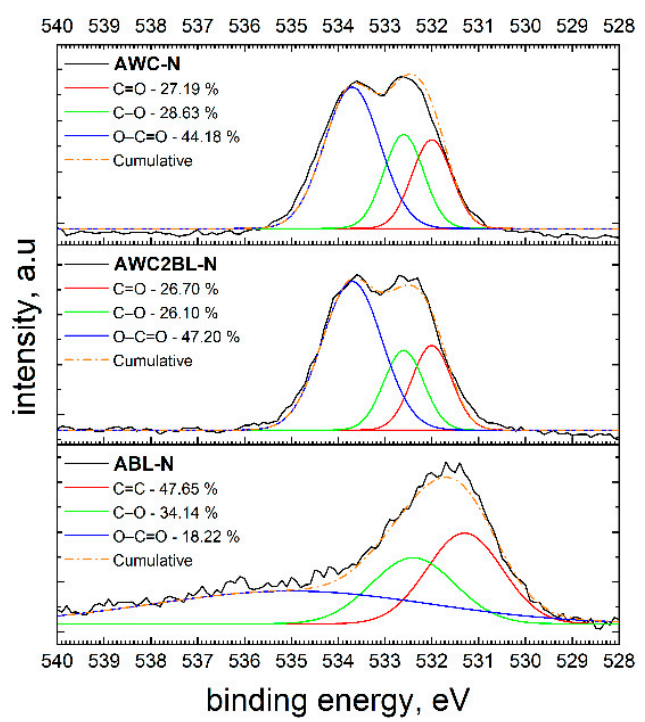

(c)

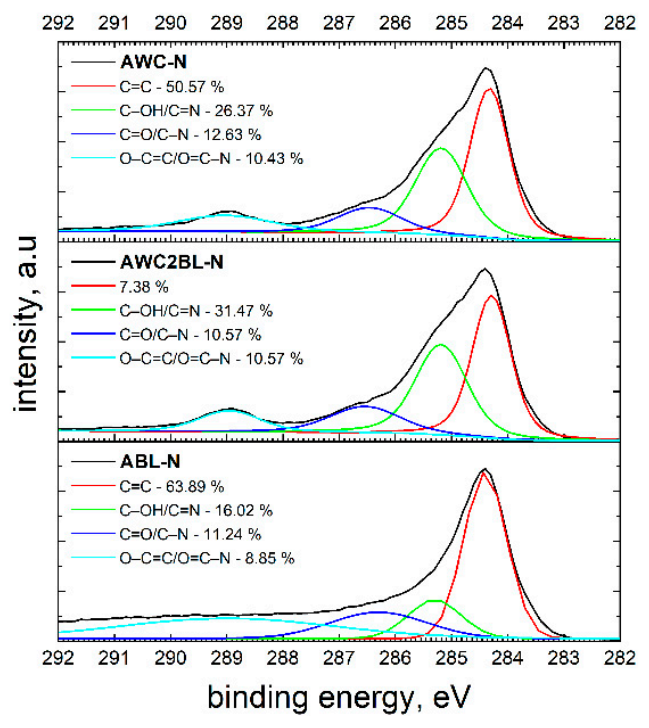

(b)

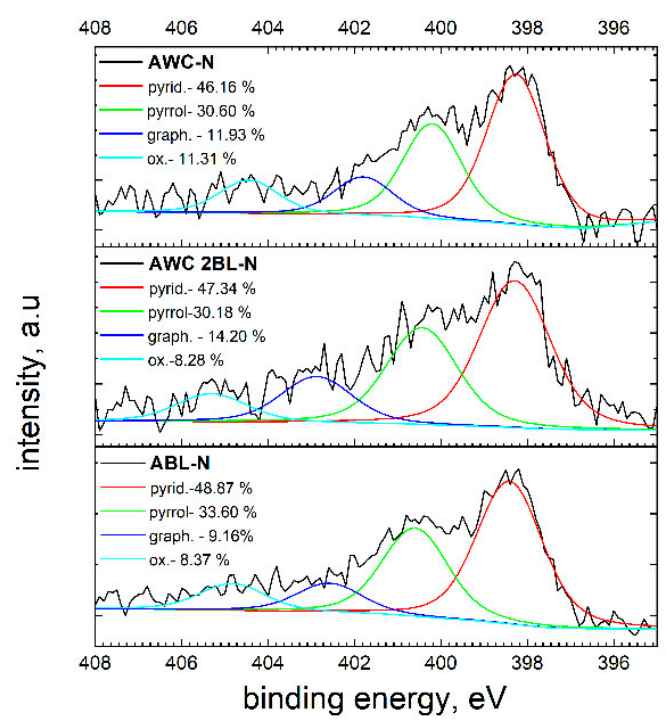

(d)

Figure 3. (a) XPS survey, (b) C 1s and (c) O 1s and (d) N 1s spectra of N-doped activated carbon based on wood char (AWC-N), N-doped activated carbon based on wood char and black liquor (AWC2BL-N) and N-doped activated carbon based on black liquor (ABL-N).

Multiple $C$ chemical states on the surface of carbons were confirmed by the high resolution of $\mathrm{C} 1$ speak (Figure $3 \mathrm{~b}$ ), which can be deconvoluted into peaks at around 284.5, 285.1 and $287.4 \mathrm{eV}$, corresponding to $\mathrm{C}-\mathrm{C} / \mathrm{C}=\mathrm{C}, \mathrm{C}-\mathrm{O} / \mathrm{C}=\mathrm{N}, \mathrm{C}=\mathrm{O} / \mathrm{C}-\mathrm{N}$ and $\mathrm{O}-\mathrm{C}=\mathrm{O} / \mathrm{O}=\mathrm{C}-$ $\mathrm{N}$, respectively [41]. Most of the carbon atoms remain bonded together in a conjugated honeycomb lattice (sp2-C and sp3-C bonds). The main component in all obtained N-doped 
AC samples correspond to the presence of $\mathrm{C}$ atoms as graphitelike sp2 C-C bonds, especially in the case of ABL-N.

The XPS survey spectra illustrate (Figure 3a) that ABL-N has significantly less oxygen than AWC-N and AWCBL-N, and after deconvolution of the O1s peak it can be observed that the way it binds is different as well (Figure 3c).

The deconvoluted high resolution spectra of N1s peak of all three samples is shown in Figure 3d, indicating the presence of four peaks: pyridinic- $\mathrm{N}$ at $398.2 \mathrm{eV}$ binding energy (AWC-N-46\%, AWC2BL-N-47\%, ABL-N-49\%), followed by pyrrolic-N at $400.2 \mathrm{eV}$ (AWC-N-31\%, AWC2BL-N-30\%, ABL-N-34\%), graphitic-N at $402.4 \mathrm{eV}$ (AWC-N-12\%, AWC2BL-N-14\%, ABL-N-9\%) and N-O at 405 eV (AWC-N-11\%, AWC2BL-N-8\%, ABL-N-8\%). Lai et al. [42] found that graphitic $\mathrm{N}$ increases the limiting current density and that pyridinic $\mathrm{N}$ improves onset potential. Experiments $[43,44]$ and theoretical calculations described in the literature have shown that nitrogen in the form of pyridine is the most active in the oxygen reduction reaction.

The crystallite structure and characteristics of the activated carbons (AWC-N, AWC2BL$\mathrm{N}$ and ABL-N) were investigated using Raman spectrometry and XRD analyses. The three Raman spectra shown in Figure $4 \mathrm{a}$ are both dominated by two intense bands, which are attributed to vibrational modes involving $\mathrm{sp}^{2}$-bonded carbon atoms belonging to disordered microcrystalline domains. The origin of the band at $\sim 1350 \mathrm{~cm}^{-1}$ (band D, or D1 in the specialized literature) has been debated for a long time; it is usually assigned to a lattice breathing mode with A1g symmetry, which is forbidden in ideal graphitic crystals, but becomes Raman active in the presence of structural disorder. For crystalline graphite, the $G$ mode has E2g symmetry and gives a band at about $1580 \mathrm{~cm}^{-1}$ and is commonly assigned to the bond stretching of pairs of $\mathrm{sp}^{2}$ carbon atoms (either in aromatic rings or chains). Though the observed Raman shift of the D band varies with the laser wavelength, the appearance of the $\mathrm{D}$ band is related to the structural disorder at defect sites [45]. The area ratio of the D band to the $G$ band is correlated with the disordered structure and the ratio will increase with increasing disorder [46]. The integral ratio $\left(\mathrm{I}_{\mathrm{D}} / \mathrm{I}_{\mathrm{G}}\right)$ is estimated to indicate the degree of structural disorder with respect to a perfect graphitic structure [47]. In the present study, the ratios of AWC-N, AWC2BL-N and ABL-N reached 0.99, 0.88 and 0.87, respectively. The relative intensity ratio of the $\mathrm{D}$ and $\mathrm{G}$ bands (ID/IG) reflects the defect density on the surface of carbons under study, that is, the smaller the ID/IG ratio, the higher the degree of ordering in the carbon material. The ID/IG value of the AWC-N was smaller compared with that of AWC2BL-N and ABL-N due to a higher level of structural defects, which is in good agreement with XRD study. Compared to the AWC-N AWC2BL-N and ABL-N ID/IG decreases, which indicate the higher degree of ordering, there were fewer defects and the presence of fewer functional groups on the surface of the material. This makes AWC-N a more promising material from the standpoint of electrochemical reactions.

As already reported in the literature, the monolayer graphene sheets will give rise to a single and sharp 2D peak located below $2700 \mathrm{~cm}^{-1}$, while the bilayer graphene sheets have a broader 2D peak and graphene sheets with more than five layers have a broad 2D peak with the positions shifted [48]. Therefore, the Raman spectrum indicates that AWC-N and AWC2BL-N samples have areas with more than five graphene layers, while ABL-N has areas with fewer than five graphene layers.

Figure $4 \mathrm{~b}$ displays the XRD patterns of N-doped activated carbon samples-all of them exhibit peaks at $26.5^{\circ}$ and $43^{\circ}$, which correspond to $C(002)$ and $C(100)$. In the X-ray diffractogram of graphite, the (002) peak is attributed to the carbon aromatic ring orientation in three-dimensional arrangement, but the (100) peak is attributed to the aromatic ring condensation degree [49]. AWC2BL has broad and barely visible (002) peak, but in case of the AWC-N and ABL-N it is narrower, which indicates a more ordered orientation of aromatic layers. The XRD pattern of the AWC-N show a broad and barely visible (100) peak while AWC2BL and ABL have narrow (100) peaks which indicate the size of the aromatic slice [50]. The peak at around $64^{\circ}$ belongs to the (103) crystal plane reflections assigned to graphite [51]. These are characteristics of a typical graphitic structure and are 
associated with the crystallite dimensions, becoming more prominent with the treatment of carbonaceous materials at higher temperatures [52]. In case of the AWC2BL-N and ABL-N $\mathrm{Fe}$, peaks were observed at $37.5^{\circ}(311)$ and $62.5^{\circ}(440)$, which could be related to magnetite $\left(\mathrm{Fe}_{3} \mathrm{O}_{4}\right)$ in the activated carbon structure [53,54]. Iron in the structure of the carbon material may appear in the process of kraft-pulping, e.g., from the walls of the digester or other similar industrial equipment. It should be noted that while activated carbon is amorphous, crystallites of various sizes and orientations are a part of the amorphous carbon matrix.

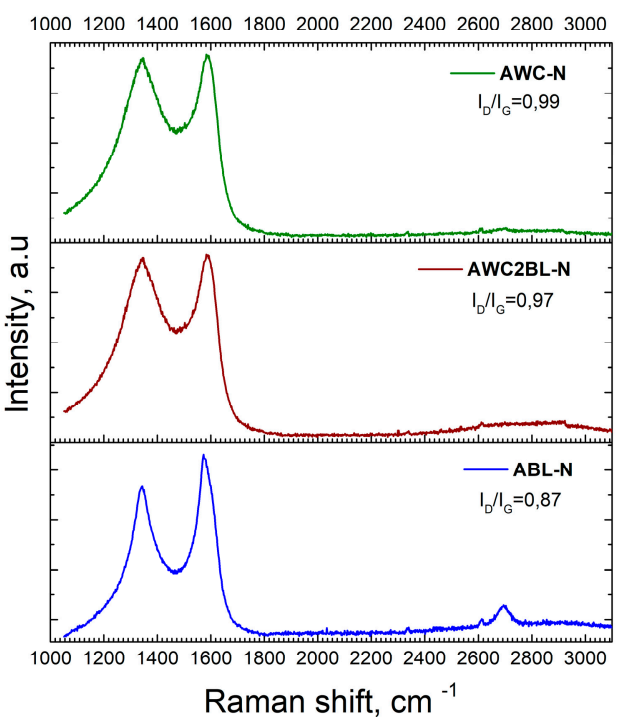

(a)

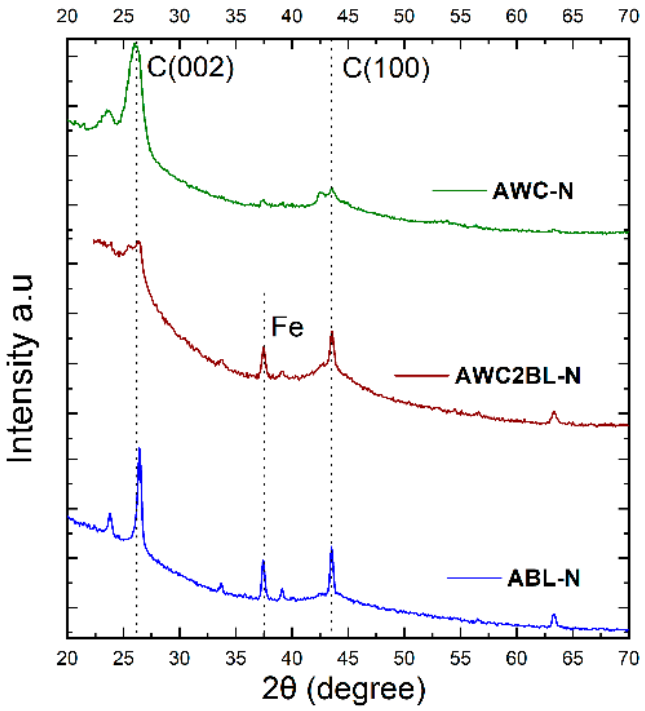

(b)

Figure 4. N-doped activated carbon based on wood char (AWC-N), N-doped activated carbon based on wood char and black liquor (AWC2BL-N) and N-doped activated carbon based on black liquor (ABL-N): (a) Raman spectra and (b) XRD.

\subsection{Electrochemical Characterization}

\subsubsection{Oxygen Reduction Reaction (ORR) on Catalysts in Alkaline Media}

The rotating disc electrode technique (RDE) is widely applied to study the oxygen reduction mechanisms at the cathode for fuel cells [55]. Figure 5a illustrates ORR polarization curves of the obtained carbon-based electrodes comparing to commercial $20 \%$ $\mathrm{Pt} / \mathrm{C}$-electrode. To evaluate the ORR activity of a catalyst material, the onset potential is an important criterion, which for AWC-N, AWC2BL-N and ABL-N is 0.09 V vs. SCE (saturated calomel electrode). Despite increasing the rotation rate, the onset potential remained the same, indicating at least short-term stability of the catalyst. AWC-N shows slightly more positive onset and half-wave potentials compared to AWC2BL-N and ABL-N, and all samples have a slight negative shift of the onset potential in comparison to $20 \%$ $\mathrm{Pt} / \mathrm{C}$. At the same time, for all samples their diffusion limited current densities reach similar values, and AWC-N and ABL-N reaches even lower value in comparison to the commercial platinum catalyst.

The number of transferred electrons per $\mathrm{O}_{2}$ molecule $(n)$ was calculated at various potentials using Koutecky-Levich (K-L) equation shown below from the ORR data [56]

$$
\frac{1}{j}=\frac{1}{j_{k}}+\frac{1}{j_{d}}=\frac{1}{j_{k}}+\frac{1}{0.62 n F D_{o_{2}}^{2 / 3} v^{-1 / 6} C_{o_{2}}^{b} \omega^{1 / 2}}
$$

where, $j$ is the ORR current density measured experimentally, $j k$ and $j d$ are the kinetic and diffusion limited current densities, respectively, F is the Faraday constant $\left(96,485 \mathrm{C} \mathrm{mol}^{-1}\right)$, $k$ is the heterogeneous rate constant for $\mathrm{O} 2$ reduction, $\omega$ is the electrode rotation rate $\left(\mathrm{rad} \mathrm{s}{ }^{-1}[57]\right), \mathrm{DO}_{2}$ is the diffusion coefficient of oxygen $\left(1.9 \times 10^{-5} \mathrm{~cm}^{2} \mathrm{~s}^{-1}[58]\right), C_{o_{2}}^{b}$ is 
the oxygen concentration $\left(1.2 \times 10^{-6} \mathrm{~mol} \mathrm{~cm}^{-3}\right.$ [58]) in $0.1 \mathrm{M} \mathrm{KOH}$, and $v$ is the kinematic viscosity of the solution $\left(0.01 \mathrm{~cm}^{2} \mathrm{~s}^{-1}\right)$.

In Figure $5 \mathrm{~b}$ AWC-N material showed a value of $n$ close to 4 at all studied potentials, meaning that this catalyst produces little to no hydrogen peroxide and is highly active for ORR. It indicates that oxygen is directly reduced to water, but it is impossible to determine via the K-L analysis if this is a direct $4{ }^{-}$electron reduction of oxygen or reduction via the $\mathrm{HO}_{2}^{-}$intermediate $\left(2 \mathrm{e}^{-}+2 \mathrm{e}^{-}\right.$reduction) pathway. For ABL-N and AWC2BL-N based electrode $\mathrm{n}$ value is around 3.5 in the potential range studied, this indicates that a rather mixed reduction process takes place.

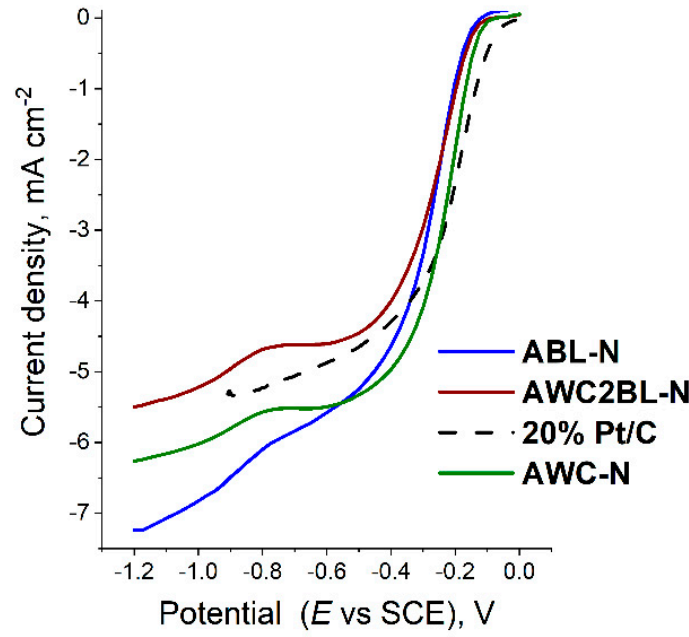

(a)

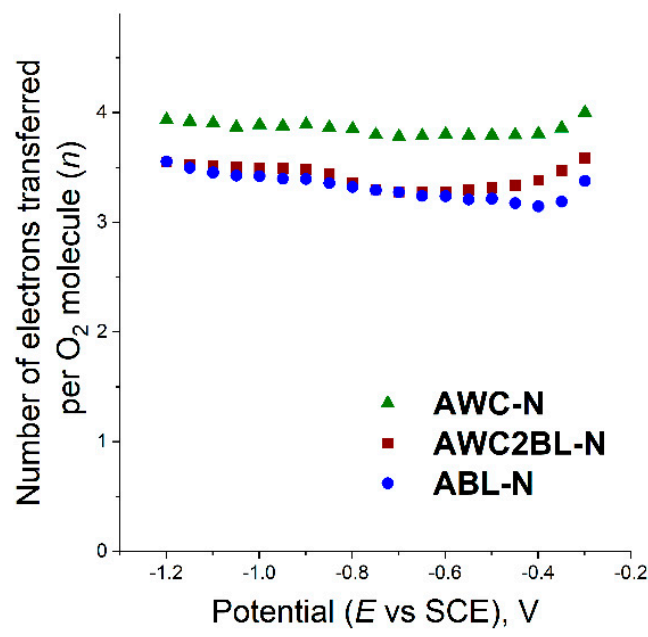

(b)

Figure 5. (a) RDE polarization curves of GC electrodes modified with N-doped activated carbon based on wood char (AWC-N), N-doped activated carbon based on wood char and black liquor (AWC2BL-N), N-doped activated carbon based on black liquor (ABL-N) and commercial $20 \% \mathrm{Pt} / \mathrm{C}$ in $\mathrm{O}_{2}$ saturated $0.1 \mathrm{M} \mathrm{KOH}\left(v=10 \mathrm{mV} \mathrm{s}^{-1}, \omega=1900 \mathrm{rpm}\right)$ and $(\mathbf{b})$ the potential dependence of number of electrons transferred per $\mathrm{O}_{2}$ molecule $(n)$.

\subsubsection{Anode Material in Li Ion Batteries}

Carbon materials are currently the most popular commercialized anode material for Li-ion batteries because of their relative high capacity, long cycle life, low cost, and ease of processing. However, the limited theoretical capacity (330 mAh g ${ }^{-1}$ [59]) makes it difficult to use in the application of Li-ion batteries with higher energy density and fast chargeability.

$\mathrm{N}$-doped activated carbons (AWC-N, AWC2BL-N and ABL-N) were tested as anode materials for lithium-ion batteries. Cyclic voltammogram tests were performed on a Battery Test Station BioLogic VMP3 electrochemical workstation within a voltage window of $0.05-3.0 \mathrm{~V}$ at a scan rate of $1 \mathrm{mVs}^{-1}$ to analyse the charging/discharging mechanisms of electrodes for Li-ion batteries. The peaks occurring during these measurements should represent phase transformations, redox reactions, lithiation and delithiation at different potentials [60]. Cyclic voltammogram profiles of AWC-N, AWC2BL-N and ABL-N are shown in Figure $6 \mathrm{a}, \mathrm{c}, \mathrm{e}$. In the first cycle, lithiation peaks can be clearly observed at $0.2 \mathrm{~V}$, originating from the lithiation of carbon species [61] and $0.72 \mathrm{~V}$ potential for AWC-N and $0.75 \mathrm{~V}$ for AWC2BL-N, and the wide peak at $0.47 \mathrm{~V}$ for ABL-N, which can be attributed to the formation of the solid electrolyte interface (SEI) film on the surface of the anode materials and the reactions between lithium ions and the functional groups on the surface of the materials [62,63]. Further CV cycling profiles showed good electrochemical reaction reversibility, which indicates that this new battery is rechargeable [64]. 


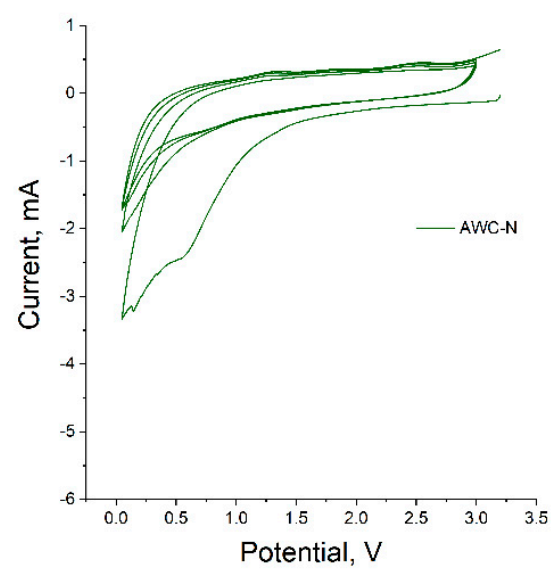

(a)

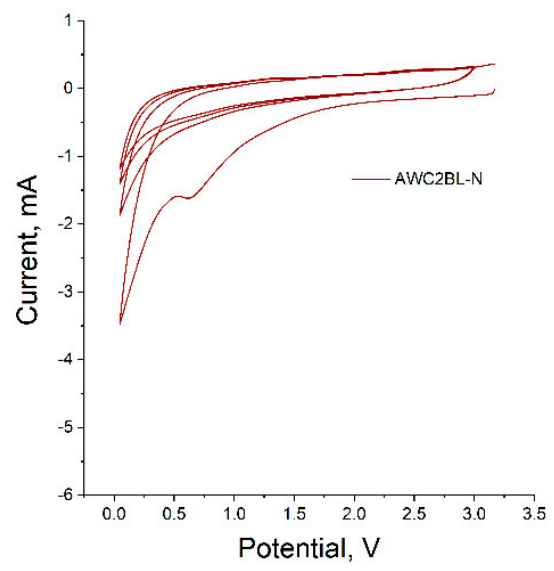

(c)

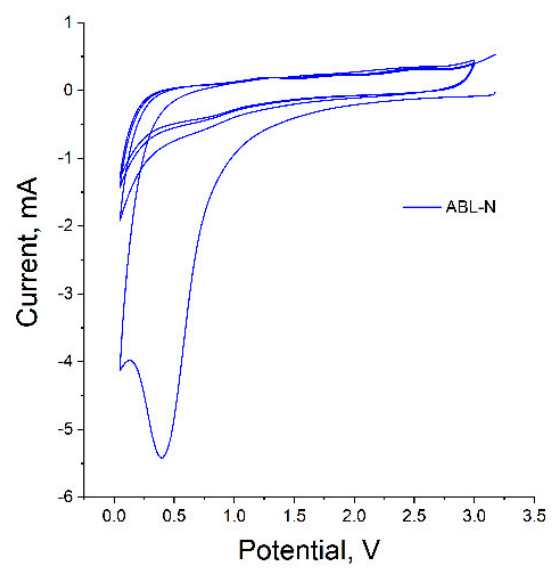

(e)

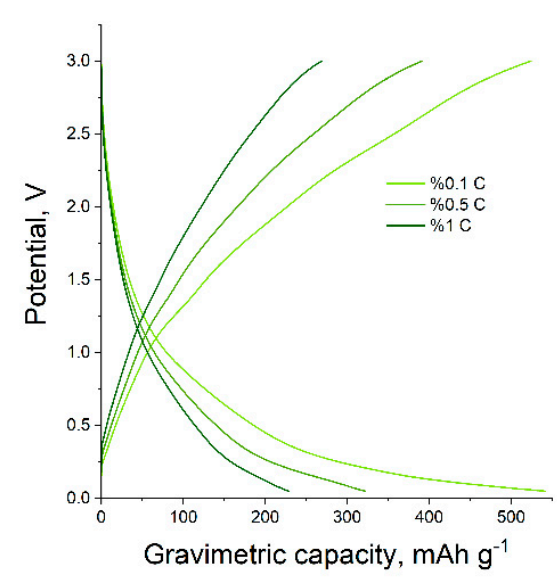

(b)

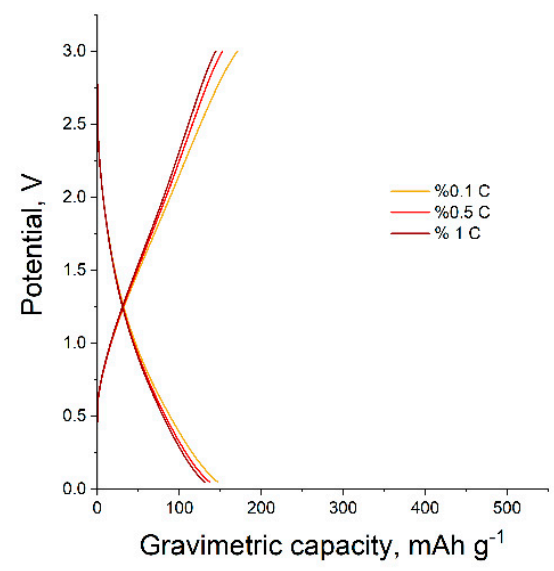

(d)

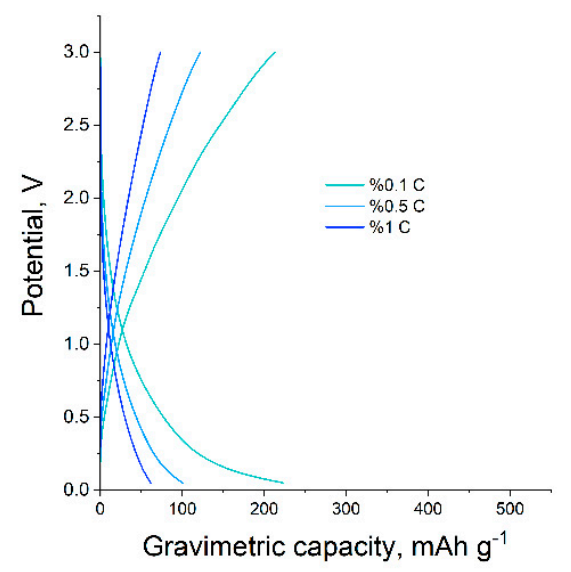

(f)

Figure 6. Cyclic Voltammogram profiles of (a) N-doped activated carbon based on wood char (AWC-N), (c) N-doped activated carbon based on wood char and black liquor (AWC2BL-N), (e) N-doped activated carbon based on black liquor (ABL-N); Galvanostatic charge-discharge profiles of (b) AWC-N, (d) AWC-2BL-N and (f) ABL-N electrodes at potential range $0.05-3.00 \mathrm{~V}$.

Galvanostatic charge-discharge profiles of the batteries were recorded in the potential window $0.05-3.0 \mathrm{~V}$. The rate performance and voltage profiles of electrodes at the charge- 
discharge rate of $0.1 \mathrm{C}, 0.5 \mathrm{C}$ and $1 \mathrm{C}$ are shown in Figure $6 \mathrm{~b}$,d,f. The sample AWC-N demonstrates a high performance and maintains gravimetric capacity of $543 \mathrm{mAh} \mathrm{g}^{-1}$ at the discharge rate of $0.1 \mathrm{C}$. A gradual decrease in discharge capacity vs. current rate is obvious for AWC-N and ABL-N samples. At the highest value of discharge, the gravimetric capacity decreases to $232 \mathrm{mAh} \mathrm{g}^{-1}$ for AWC-N, $64 \mathrm{mAh} \mathrm{g}^{-1}$ for ABL-N and $126 \mathrm{mAh} \mathrm{g}^{-1}$ for AWC2BL-N. The gravimetric capacity was calculated based on the total mass of the electrode material. The AWC-N shows excellent electrochemical behaviour and superior performance compared to AWCBL-N and ABL-N. The gravimetric capacity for AWC-2BL$\mathrm{N}$ is only $50 \%$ of the capacity of AWC-N, but the sample ABL-N has approximately $30 \%$ of the capacity of AWC-N at a discharge rate of $0.1 \mathrm{C}$.

Figure 7 shows a lithium-ion storage capacity vs. cycle number at $0.5 \mathrm{C}$. The capacity retention after 500 cycles of AWC-N was $\sim 19 \%$ and for ABL-N was $\sim 5 \%$. The capacity retention after 300 cycles of AWC2BL-N was $\sim 71 \%$. This can be explained by interfacial lithium storage, inevitable formation of the SEI layer and electrolyte decomposition, which are common for most anode materials [65]. The gravimetric capacities of ABL-N electrodes after 500 cycles are $10 \mathrm{mAh} \mathrm{g}^{-1}$ and for AWC-N is $94 \mathrm{mAhg}^{-1}$. Before the degradation of anode material at 300 cycles, AWC2BL-N maintains a gravimetric capacity of $104 \mathrm{mAh} \mathrm{g}^{-1}$.

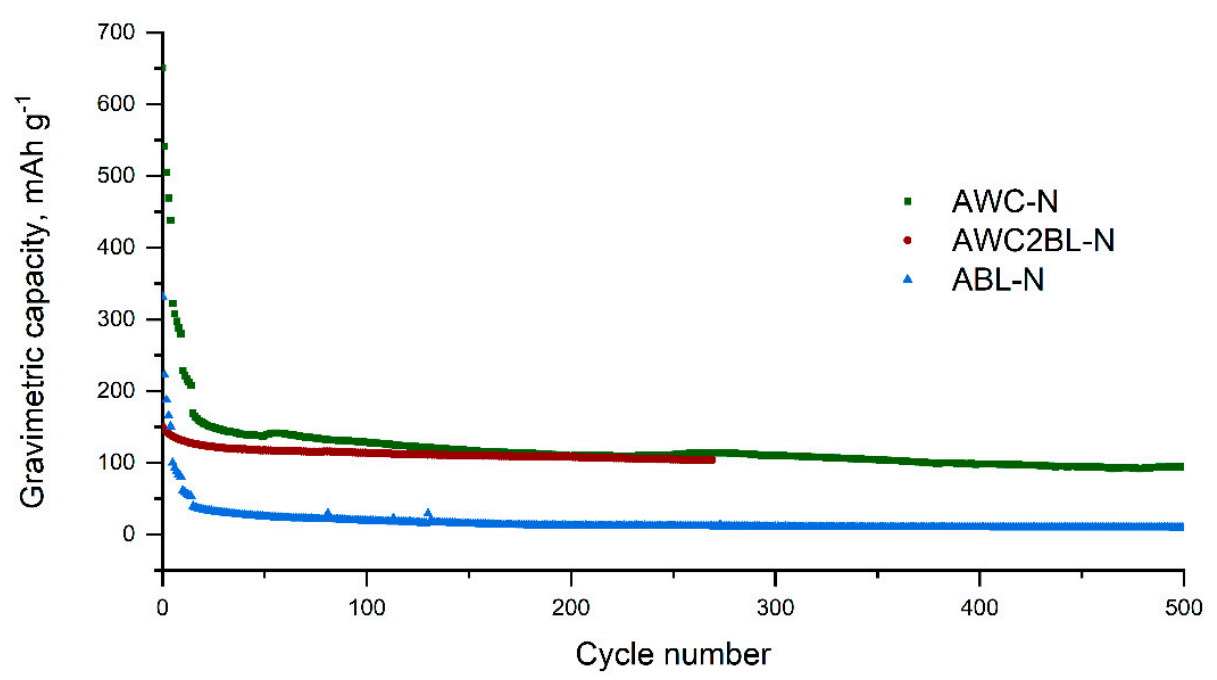

Figure 7. AWC-N, AWC2BL-N and ABL-N reversible lithium storage capacities vs. cycle number at the charge-discharge rate $0.5 \mathrm{C}$.

Compered to commercial above-mentioned carbon anode material, AWC-N displays $65 \%$ higher gravimetric capacity. The electrochemical performance data of different carbon anode materials from the literature are listed in Table 3 and compered to obtained $\mathrm{N}$ doped activated carbons (AWC-N, AWC2BL-N and ABL-N) - the battery in this work is among the highest performing. It is worth mentioning that graphene and graphene oxide have superior performance, but are expensive and in limited production capacity, i.e., they cannot be obtained in large quantities. Considering capacity, cyclic stability and electrochemical reaction reversibility, we believe that the AWC-N is a relatively cheap and renewable electrode material for high-performance Li-ion battery anode materials. 
Table 3. Electrochemical performance comparison of carbon anode materials.

\begin{tabular}{|c|c|c|c|c|c|}
\hline $\begin{array}{l}\text { Electrode } \\
\text { Material }\end{array}$ & $\begin{array}{l}\text { Working Potential } \\
\text { Range, V }\end{array}$ & Electrolyte & $\begin{array}{c}\text { Gravimetric } \\
\text { Capacity, mAh } \mathrm{g}^{-1}\end{array}$ & $\begin{array}{l}\text { Capacity } \\
\text { Retention }\end{array}$ & Ref. \\
\hline $\begin{array}{l}\text { Graphene } \\
\text { oxide paper }\end{array}$ & $0.01-3.0$ & - & 702 at $50 \mathrm{mAg}^{-1}$ & $73 \%$ after 55 cycles & [66] \\
\hline $\begin{array}{l}\text { Functionalized } \\
\text { graphene paper }\end{array}$ & $0.01-3.0$ & $\begin{array}{c}1.15 \mathrm{M} \mathrm{LiPF}_{6} \text { in } \\
\text { EC:EMC:DMC }(3: 2: 5)\end{array}$ & 450 at $300 \mathrm{mAg}^{-1}$ & - & [67] \\
\hline $\mathrm{Si} / \mathrm{C}$ composite & $0.01-1.2$ & $\begin{array}{c}\text { 1.0 } \mathrm{M} \mathrm{LiPF}_{6} \text { in EC: PC: } \\
\mathrm{DMC}_{(1: 1: 1)}\end{array}$ & 455 at $0.1 \mathrm{C}$ & $78 \%$ after 40 cycles & [68] \\
\hline AWC-N & $0.05-3.0$ & $\mathrm{LiPF}_{6}$ in EC: DMC (1:1) & 543 at $0.5 \mathrm{C}$ & $26 \%$ after 50 cycles & \\
\hline AWC2BL-N & $0.05-3.0$ & $\mathrm{LiPF}_{6}$ in EC: DMC (1:1) & 149 at $0.5 \mathrm{C}$ & $78 \%$ after 50 cycles & \\
\hline ABL-N & $0.05-3.0$ & $\mathrm{LiPF}_{6}$ in EC: DMC (1:1) & 224 at $0.5 \mathrm{C}$ & $12 \%$ after 50 cycles & \\
\hline
\end{tabular}

\section{Conclusions}

To investigate the possibility of the application of nanoporous nitrogen-doped carbon materials as catalysts in fuel cells and as electrodes in lithium-ion batteries, biomass precursors were thermochemically activated with $\mathrm{NaOH}$ at $800^{\circ} \mathrm{C}$, nitrogen was introduced using dicyandiamide and doping was performed at $800{ }^{\circ} \mathrm{C}$. Depending on the precursor used-wood char, byproduct of kraft pulp production—black liquor and hybrid materialwood char impregnated with black liquor, the porous structures of the obtained carbon materials had large specific surface areas and different pore size distribution.

It was found that after the activation of wood char, either separately or as a part of the hybrid material, provides a microporous structure with micropore volume $0.8 \mathrm{~cm}^{3} \mathrm{~g}^{-1}$ and a specific surface area more than $2500 \mathrm{~m}^{2} \mathrm{~g}^{-1}$, while the predominant development of mesopores, in the case of black liquor, provides a two times larger average pore size of $4.6 \mathrm{~nm}$.

It is shown that $\mathrm{N}$-doping of the obtained carbon materials leads to the introduction of approximately $4 \%$ of nitrogen. As a result of doping in the case of samples containing wood char the porosity parameters are reduced. On the contrary, in the case of black liquor doping, both the total pore volume and the specific surface area increase, possibly due to the replacement of not only oxygen, but also sulphur with nitrogen, which has a lower atomic mass. The results of the XPS analysis showed that the introduced nitrogen formed three types of bonds and the predominant one (more than $45 \%$ from all $\mathrm{N}$ ) for all samples is the most electrochemically active pyridine form.

From the results of XRD and Raman spectra it can be concluded that all obtained $\mathrm{N}$-doped activated carbon materials have an amorphous matrix with crystallites of different sizes and orientations. Comparing $\mathrm{N}$-doped activated carbon based on black liquor with wood char-based samples, the structure of the former has fewer defects and graphenelike areas. SEM and TEM studies demonstrate that precursor also affects the morphology of the material. In the case of $\mathrm{N}$-doped activated carbon based on black liquor particles, there are coarse layered agglomerates with a dense core and a less dense structure at the outer edges. In contrast, wood char-based and hybrid samples have a curved and wavy surface with a graphenelike shell and a dense core.

Analysing the results of the oxygen reduction reaction and comparing them with our previously published data, where carbon activation was performed at a lower temp at $700{ }^{\circ} \mathrm{C}[9,69]$, it was concluded that increasing the activation temperature improves the electrochemical properties. All samples have a slight negative shift of the onset potential in comparison with $20 \% \mathrm{Pt} / \mathrm{C}$. At the same time, for all samples, diffusion limited current densities are reaching similar values and in the case of catalysts based on wood char and based on black liquor they reach an even lower value, showing better results in comparison to the commercial platinum catalyst. However, AWC-N showed the highest number of transferred electrons per $\mathrm{O}_{2}$ molecule, close to 4 , at all studied potentials, but for ABL- 
$\mathrm{N}$ and AWC2BL-N the values are lower, around 3.5. Obviously, not only the material composition of the surface functional groups and the porous structure, but also the texture, affects the activity, stability, and binding ability of the catalyst.

Performing Li-ion battery experiments for all samples in the first cycle of the voltammogram lithiation and the formation of a solid electrolyte layer are observed, and as a result the charge capacity decreases $\sim 3$ times after this cycle. It should be noted that $\mathrm{N}$-doped activated carbon based on wood char shows the highest gravimetric capacity (543 $\mathrm{mAh} \mathrm{g}^{-1}$ ) compared to N-doped activated carbon based on black liquors and hybrid precursors (which demonstrated only $30 \%$ and $50 \%$ of AWC-N, respectively).

The chemical composition, porous structure, texture and electrochemical properties of the obtained materials change depending on the biomass precursor used. It has been found that the most promising precursor of the obtained materials is wood char, both as an oxygen reduction catalyst in fuel cells, which shows better properties than the commercial $20 \% \mathrm{Pt} / \mathrm{C}$ catalyst, and as an anode material in Li-ion batteries. The electrochemical activity of the precursors used decreases in the following order: wood char > hybrid material > black liquor.

However, black liquor is a byproduct and catalysts and electrodes based on black liquor and hybrid material can be considered as a cheaper alternative.

Author Contributions: Conceptualization, A.P. and G.D.; methodology, A.V., K.K. (Kätlin Kaare) and K.K. (Kaspars Kaprans); validation and formal analysis, A.P., G.D., K.K. (Kätlin Kaare) and K.K. (Kaspars Kaprans); resources and data curation, A.P., K.K. (Kätlin Kaare) and K.K. (Kaspars Kaprans); writing-original draft preparation, A.P. writing-review and editing, A.V. and A.K.; visualization, A.P.; supervision, G.D., A.Z., I.K. and J.K.; project administration and funding acquisition, A.Z. and J.K. All authors have read and agreed to the published version of the manuscript.

Funding: The research was funded by the Latvian Council of Science project "Nanostructured Nitrogenated Carbon Materials as Promoters in Energy Harvesting and Storage Technologies" project No LZP-2018/1-0194, "New biomass origin materials hybrid carbon composites for energy storage" project No LZP-2020/2-0019, postdoc project "Nitrogen and phosphorus-containing biomass based activated carbons for fuel cells and supercapacitors" project No 1.1.1.2/VIAA/4/20/596 and by European Regional Development Fund "Emerging orders in quantum and nanomaterials" project No. TK134 (EQUiTANT).

Institutional Review Board Statement: Not applicable.

Informed Consent Statement: Not applicable.

Data Availability Statement: The data presented in this study are available on request from the corresponding author.

Acknowledgments: The authors would like to thank the Latvian State Institute of Wood Chemistry, the Institute of Solid State Physics (University of Latvia), Riga Technical University, the Faculty of Material Science and Applied Chemistry and the National Institute of Chemical Physics and Biophysics (Estonia) for the support provided.

Conflicts of Interest: The authors declare no conflict of interest.

\section{References}

1. Kumar, R.; Sahoo, S.; Joanni, E.; Singh, R.K.; Tan, W.K.; Kar, K.K.; Matsuda, A. Recent progress in the synthesis of graphene and derived materials for next generation electrodes of high performance lithium ion batteries. Prog. Energy Combust. Sci. 2019, 75, 100786. [CrossRef]

2. Vaalma, C.; Buchholz, D.; Weil, M.; Passerini, S. A cost and resource analysis of sodium-ion batteries. Nat. Rev. Mater. 2018, 3, 1-11. [CrossRef]

3. Zhang, H.; Sun, C.Y. Cost-effective iron-based aqueous redox flow batteries for large-scale energy storage application: A review. J. Power Sources 2021, 493, 229445. [CrossRef]

4. Tripathi, M.; Sahu, J.N.; Ganesan, P. Effect of process parameters on production of biochar from biomass waste through pyrolysis: A review. Renew. Sustain. Energy Rev. 2016, 55, 467-481. [CrossRef]

5. Kluska, J.; Ochnio, M.; Kardaś, D.; Heda, L. The influence of temperature on the physicochemical properties of products of pyrolysis of leather-tannery waste. Waste Manag. 2019, 88, 248-256. [CrossRef] [PubMed] 
6. Zhou, X.X.; Moghaddam, T.B.; Chen, M.Z.; Wu, S.P.; Zhang, Y.; Zhang, X.R.; Adhikari, S.; Zhang, X. Effects of pyrolysis parameters on physicochemical properties of biochar and bio-oil and application in asphalt. Sci. Total Environ. 2021, 780, 146448. [CrossRef] [PubMed]

7. Kumar, R.; Sahoo, S.; Joanni, E.; Singh, R.K.; Maegawa, K.; Tan, W.K.; Kawamura, G.; Kar, K.K.; Matsuda, A. Heteroatom doped graphene engineering for energy storage and conversion. Mater. Today 2020, 39, 47-65. [CrossRef]

8. Niu, J.; Shao, R.; Liang, J.J.; Dou, M.L.; Li, L.Z.; Huang, Y.Q.; Wang, F. Biomass-derived mesopore-dominant porous carbons with large specific surface area and high defect density as high performance electrode materials for Li-ion batteries and supercapacitors. Nano Energy 2017, 36, 322-330. [CrossRef]

9. Volperts, A.; Plavniece, A.; Dobele, G.; Zhurinsh, A.; Kruusenberg, I.; Kaare, K.; Locs, J.; Tamasauskaite-Tamasiunaite, L.; Norkus, E. Biomass based activated carbons for fuel cells. Renew. Energy 2019, 141, 40-45. [CrossRef]

10. Liu, P.; Wang, Y.Y.; Liu, J.H. Biomass-derived porous carbon materials for advanced lithium sulfur batteries. J. Energy Chem. 2019, 34, 171-185. [CrossRef]

11. Abioye, A.M.; Ani, F.N. Recent development in the production of activated carbon electrodes from agricultural waste biomass for supercapacitors: A review. Renew. Sustain. Energy Rev. 2015, 52, 1282-1293. [CrossRef]

12. Wang, M.K.; Cheng, S.; Yao, M.H.; Zhu, Y.Y.; Wu, P.; Luo, H.W.; Yang, L.F.; Tang, L.J.; Liu, M.L. Synthesis of biomass-derived 3D porous graphene-like via direct solid-state transformation and its potential utilization in lithium-ion battery. Ionics (Kiel) 2018, 24, 1879-1886. [CrossRef]

13. Balčiūnaitè, A.; Budrytè, E.; Vaičiūnienè, J.; Niaura, G.; Kruusenberg, I.; Kaare, K.; Volperts, A.; Dobele, G.; Zurins, A.; Tamašauskaitè-Tamašiūnaitè, L.; et al. One-Pot Synthesis of Nitrogen-Doped Carbon Supported Mn-Co Nanoparticles for Hydrazine Oxidation. ECS Trans. 2020, 97, 593-603. [CrossRef]

14. Bandosz, T.J.; Ren, T. Porous carbon modified with sulfur in energy related applications. Carbon N. Y. 2017, 118, 561-577. [CrossRef]

15. Xiong, D.B.; Li, X.F.; Fan, L.L.; Bai, Z.M. Three-dimensional heteroatom-doped nanocarbon for metal-free oxygen reduction electrocatalysis: A review. Catalysts 2018, 8, 301. [CrossRef]

16. Ouyang, D.D.; Hu, L.B.; Wang, G.; Dai, B.; Yu, F.; Zhang, L.L. A review of biomass-derived graphene and graphene-like carbons for electrochemical energy storage and conversion. New Carbon Mater. 2021, 36, 350-372. [CrossRef]

17. Chen, N.; Zhang, H.; Luo, X.D.; Sun, C.Y. SiO2-decorated graphite felt electrode by silicic acid etching for iron-chromium redox flow battery. Electrochim. Acta 2020, 336, 135646. [CrossRef]

18. Dobele, G.; Dizhbite, T.; Gil, M.V.; Volperts, A.; Centeno, T.A. Production of nanoporous carbons from wood processing wastes and their use in supercapacitors and CO2 capture. Biomass Bioenergy 2012, 46, 145-154. [CrossRef]

19. Volperts, A.; Dobele, G.; Zhurinsh, A.; Vervikishko, D.; Shkolnikov, E.; Ozolinsh, J. Wood-based activated carbons for supercapacitor electrodes with a sulfuric acid electrolyte. Xinxing Tan Cailiao/New Carbon Mater. 2017, 32, 319-326. [CrossRef]

20. Bansal, R.C.; Goyal, M. Activated Carbon Adsorption; CRC Press: Boca Raton, FL, USA, 2005.

21. Abbas, Q.; Raza, R.; Shakir, I.; Olabi, A.G. Heteroatom doped high porosity carbon nanomaterials as electrodes for energy storage in electrochemical capacitors: A review. J. Sci. Adv. Mater. Devices 2019, 4, 341-352. [CrossRef]

22. Flowers, P.; Neth, E.J.; Robinson, W.R.; Theopold, K.; Langley, R.E. Chemistry: Atoms First, 2nd ed.; OpenStax: Houston, TX, USA, 2019.

23. Rauls, E.; Gerstmann, U.; Frauenheim, T.; Overhof, H. The different behavior of nitrogen and phosphorus as n-type dopants in SiC. Phys. B Condens. Matter 2003, 340-342, 184-189. [CrossRef]

24. Bajwa, D.S.; Pourhashem, G.; Ullah, A.H.; Bajwa, S.G. A concise review of current lignin production, applications, products and their environment impact. Ind. Crop. Prod. 2019, 139, 111526. [CrossRef]

25. Mandeep; Gupta, G.K.; Liu, H.; Shukla, P. Pulp and paper industry-based pollutants, their health hazards and environmental risks. Curr. Opin. Environ. Sci. Health 2019, 12, 48-56.

26. Haile, A.; Gelebo, G.G.; Tesfaye, T.; Mengie, W.; Mebrate, A.A.; Abuhay, A.; Limeneh, D.Y. Pulp and paper mill wastes: Utilizations and prospects for high value-added biomaterials. Bioresour. Bioprocess. 2021, 8, 35. [CrossRef]

27. Viel, M.; Collet, F.; Lanos, C. Effect of compaction on multi-physical properties of hemp-black liquor composites. J. Mater. Res. Technol. 2020, 9, 2487-24940. [CrossRef]

28. Eugenio, M.E.; Ibarra, D.; Martín-Sampedro, R.; Espinosa, E.; Bascón, I.; Rodríguez, A. Alternative Raw Materials for Pulp and Paper Production in the Concept of a Lignocellulosic Biorefinery. In Cellulose; Pascual, A.R., Martin, M.E.E., Eds.; BoD—Books on Demand: London, UK, 2019; p. 78.

29. Collard, F.-X.; Blin, J. A review on pyrolysis of biomass constituents: Mechanisms and composition of the products obtained from the conversion of cellulose, hemicelluloses and lignin. Renew. Sustain. Energy Rev. 2014, 38, 594-608. [CrossRef]

30. Cheremisinoff, N.P.; Rosenfeld, P. Sources of air emissions from pulp and paper mills. In Handbook of Pollution Prevention and Cleaner Production; Elsevier: Amsterdam, Holland, The Netherlands, 2010; pp. 179-259.

31. Wang, J.; Kaskel, S. KOH activation of carbon-based materials for energy storage. J. Mater. Chem. 2012, 22, 23710-23725. [CrossRef]

32. Van, K.L.; Thu, T.L.T.; Thu, T.N.H.; Hoang, V.H. Activated Carbon by KOH and NaOH Activation: Preparation and Electrochemical Performance in $\mathrm{K}_{2} \mathrm{SO}_{4}$ and $\mathrm{Na}_{2} \mathrm{SO}_{4}$ Electrolytes. Russ. J. Electrochem. 2019, 55, 900-907.

33. Ndifreke, W.E.; Aydinlik, N.P. KOH modified Thevetia peruviana shell activated carbon for sorption of dimethoate from aqueous solution. J. Environ. Sci. Health Part B 2018, 54, 1-13. [CrossRef] 
34. Gunasekaran, S.S.; Elumalali, S.K.; Kumaresan, T.K.; Meganathan, R.; Ashok, A.; Pawar, V.; Vediappan, K.; Ramasamy, G.; Karazhanov, S.Z.; Raman, K.; et al. Partially graphitic nanoporous activated carbon prepared from biomass for supercapacitor application. Mater. Lett. 2018, 218, 165-168. [CrossRef]

35. Dobele, D.; Vervikishko, D.; Volperts, A.; Bogdanovich, N.; Shkolnikov, E. Characterization of the pore structure of nanoporous activated carbons produced from wood waste. Holzforschung 2013, 67, 587-594. [CrossRef]

36. Liu, Y.; Li, K.S.; Ge, B.C.; Pu, L.T.; Liu, Z.Q. Influence of Micropore and Mesoporous in Activated Carbon Air-cathode Catalysts on Oxygen Reduction Reaction in Microbial Fuel Cells. Electrochim. Acta 2016, 214, 110-118. [CrossRef]

37. Xing, Z.; Ju, Z.C.; Zhao, Y.L.; Wan, J.L.; Zhu, Y.B.; Qiang, Y.H.; Qian, Y.T. One-pot hydrothermal synthesis of Nitrogen-doped graphene as high-performance anode materials for lithium ion batteries. Sci. Rep. 2016, 6, 1-10. [CrossRef]

38. Shruthi, T.K.; Kumar, M.S.; Arjunan, M.; Pratap, A.; Chandrasekaran, N. Graphene oxide aided structural tailoring of 3-D $\mathrm{N}$-doped amorphous carbon network for enhanced energy storage. RSC Adv. 2015, 5, 93423-93432. [CrossRef]

39. Zhang, X.L.; Yu, D.L.; Zhang, Y.Q.; Guo, W.H.; Ma, X.X.; He, X.Q. Nitrogen- and sulfur-doped carbon nanoplatelets via thermal annealing of alkaline lignin with urea as efficient electrocatalysts for oxygen reduction reaction. RSC Adv. 2020, 6, 104183-104192. [CrossRef]

40. Zhang, J.M.; He, J.; Zheng, H.Y.; Li, R.; Gou, X.L. N,S dual-doped carbon nanosheet networks with hierarchical porosity derived from biomass of Allium cepa as efficient catalysts for oxygen reduction and Zn-air batteries. J. Mater. Sci. 2020, 55, 7464-7476. [CrossRef]

41. Wu, X.X.; Tian, Z.W.; Hu, L.Q.; Huang, S.; Cai, J.J. Macroalgae-derived nitrogen-doped hierarchical porous carbons with high performance for $\mathrm{H} 2$ storage and supercapacitors. RSC Adv. 2017, 7, 32795-32805. [CrossRef]

42. Lai, L.F.; Potts, J.R.; Zhan, D.; Wang, L.; Poh, C.K.; Tang, C.H.; Gong, H.; Shen, Z.X.; Lin, J.Y.; Ruoff, R.S. Exploration of the active center structure of nitrogen-doped graphene-based catalysts for oxygen reduction reaction. Energy Environ. Sci. 2012, 5 , 7936-7942. [CrossRef]

43. Guo, D.H.; Shibuya, R.; Akiba, C.; Saji, S.; Kondo, T.; Nakamura, J. Active sites of nitrogen-doped carbon materials for oxygen reduction reaction clarified using model catalyst. Science 2016, 351, 361-365. [CrossRef] [PubMed]

44. Lv, Q.; Si, W.Y.; He, J.J.; Sun, L.; Zhang, C.F.; Wang, N.; Yang, Z.; Li, X.D.; Wang, X.; Deng, W.Q.; et al. Selectively nitrogen-doped carbon materials as superior metal-free catalysts for oxygen reduction. Nat. Commun. 2018, 9, 1-11. [CrossRef]

45. Wang, Y.; Alsmeyer, C.D.; McCreery, L.R. Raman spectroscopy of carbon materials: Structural basis of observed spectra. Chem. Mater. 2002, 2, 557-563. [CrossRef]

46. Ferrari, A.C.; Robertson, J. Interpretation of Raman spectra of disordered and amorphous carbon. Phys. Rev. B 2000, 61, 14095. [CrossRef]

47. Gadipelli, S.; Guo, Z.X. Graphene-based materials: Synthesis and gas sorption, storage and separation. Prog. Mater. Sci. 2015, 69, 1-60. [CrossRef]

48. Zhang, J.; Tian, T.; Chen, Y.; Niu, Y.; Tang, J.; Qin, L.C. Synthesis of graphene from dry ice in flames and its application in supercapacitors. Chem. Phys. Lett. 2014, 591, 78-81. [CrossRef]

49. Qiu, T.; Yang, J.G.; Bai, X.J.; Wang, Y.L. The preparation of synthetic graphite materials with hierarchical pores from lignite by one-step impregnation and their characterization as dye absorbents. RSC Adv. 2019, 9, 12737-12746. [CrossRef]

50. Li, W.; Zhu, Y.M. Structural characteristics of coal vitrinite during pyrolysis. Energy Fuels 2014, 28, 3645-3654. [CrossRef]

51. Arrebola, J.C.; Caballero, A.; Hernán, L.; Morales, J. Graphitized Carbons of Variable Morphology and Crystallinity: A Comparative Study of Their Performance in Lithium Cells. J. Electrochem. Soc. 2009, 156, A986. [CrossRef]

52. Aso, H.; Matsuoka, K.; Sharma, A.; Tomita, A. Structural analysis of PVC and PFA carbons prepared at $500-1000{ }^{\circ} \mathrm{C}$ based on elemental composition, XRD, and HRTEM. Carbon 2004, 42, 2963-2973. [CrossRef]

53. Arie, A.A.; Kristianto, H.; Susanti, R.F.; Devianto, H.; Halim, M.; Lee, J.K. Structural and preliminary electrochemical characteristics of palm oil based carbon nanospheres as anode materials in lithium ion batteries. Carbon Lett. 2016, 18, 80-83. [CrossRef]

54. Yin, P.F.; Deng, Y.; Zhang, L.; Li, N.; Feng, X.; Wang, J.; Zhang, Y. Facile synthesis and microwave absorption investigation of activated carbon@Fe3O4 composites in the low frequency band. RSC Adv. 2018, 8, 23048-23057. [CrossRef]

55. Lee, S.-J.; Pyun, S.-I.; Lee, S.-K.; Kang, S.-J.L. Fundamentals of Rotating Disc and Ring-Disc Electrode Techniques and their Applications to Study of the Oxygen Reduction Mechanism at Pt/C Electrode for Fuel Cells. Isr. J. Chem. 2008, 48, 215-228. [CrossRef]

56. Kaare, K.; Yu, E.; Käämbre, T.; Volperts, A.; Dobele, G.; Zhurinsh, A.; Niaura, G.; TamasauskaiteTamasiunaite, L.; Norkus, E.; Kruusenberg, I. Biomass-derived Graphene-like Catalyst Material for Oxygen Reduction Reaction. ChemNanoMat 2021, 7, $307-313$. [CrossRef]

57. Lide, D.R. Handbook of Chemistry and Physics, 81st ed.; CRC Press: Boca Raton, FL, USA, 2000.

58. Davis, R.E.; Horvath, G.L.; Tobias, C.W. The solubility and diffusion coefficient of oxygen in potassium hydroxide solutions. Electrochim. Acta 1967, 12, 287-297. [CrossRef]

59. MCMB Mesocarbon Microbeads Graphite Powder Anode Raw Materials For Lithium Battery. Available online: https: / / www.batterymaking.com/product/mcmb-mesocarbon-microbeads-graphite-powder-anode-raw-materials-for-lithiumbattery_p158.html (accessed on 10 August 2021). 
60. Hansen, S.; Quiroga-González, E.; Carstensen, J.; Föll, H. Size-dependent cyclic voltammetry study of silicon microwire anodes for lithium ion batteries. Electrochim. Acta 2016, 217, 283-291. [CrossRef]

61. Chang, X.H.; Li, W.; Yang, J.F.; Xu, L.; Zheng, J.; Li, X.G. Direct plasma deposition of amorphous Si/C nanocomposites as high performance anodes for lithium ion batteries. J. Mater. Chem. A 2015, 3, 3522-3528. [CrossRef]

62. Wang, W.; Sun, Y.; Liu, B.; Wang, S.G.; Cao, M.H. Porous carbon nanofiber webs derived from bacterial cellulose as an anode for high performance lithium ion batteries. Carbon 2015, 91, 56-65. [CrossRef]

63. Tang, K.; White, R.J.; Mu, X.K.; Titirici, M.M.; Aken, P.V.A.; Maier, J. Hollow carbon nanospheres with a high rate capability for lithium-based batteries. ChemSusChem 2012, 5, 400-403. [CrossRef]

64. Zhou, H.T.; Wang, X.H.; Chen, D. Li-Metal-Free Prelithiation of Si-Based Negative Electrodes for Full Li-Ion Batteries. ChemSusChem 2015, 8, 2737-2744. [CrossRef]

65. Yu, K.F.; Li, J.; Qi, H.; Liang, C. High-capacity activated carbon anode material for lithium-ion batteries prepared from rice husk by a facile method. Diam. Relat. Mater. 2018, 86, 139-145. [CrossRef]

66. Cetinkaya, T.; Ozcan, S.; Uysal, M.; Guler, M.O.; Akbulut, H. Free-standing flexible graphene oxide paper electrode for rechargeable Li-O2 batteries. J. Power Sources 2014, 267, 140-147. [CrossRef]

67. Dao, T.D.; Hong, J.E.; Ryu, K.S.; Jeong, H.M. Super-tough functionalized graphene paper as a high-capacity anode for lithium ion batteries. Chem. Eng. J. 2014, 250, 257-266. [CrossRef]

68. Lee, C.-Y.; Yeh, F.-H.; Yu, I.-S. A Commercial Carbonaceous Anode with a-Si Layers by Plasma Enhanced Chemical Vapor Deposition for Lithium Ion Batteries. J. Compos. Sci. 2020, 4, 72. [CrossRef]

69. Plavniece, A.; Dobele, G.; Volperts, A.; Zhurinsh, A.; Kruusenberg, I. Wood-based nitrogen doped activated carbon for fuel cells. IOP Conf. Ser. Mater. Sci. Eng. 2019, 503, 012001. [CrossRef] 